\title{
Effects of aqueous soaking on the phytate and mineral contents and phytate:mineral ratios of wholegrain normal sorghum and maize and low phytate sorghum
}

Johanita Kruger ${ }^{\mathrm{a}}$, André Oelofse ${ }^{\mathrm{b}}$, John R.N. Taylor ${ }^{\mathrm{a}}$

\author{
${ }^{a}$ Department of Food Science and Institute for Food, Nutrition and Well-being, University of Pretoria, \\ Private Bag X20, Hatfield 0028, South Africa \\ ${ }^{b}$ Department of Human Nutrition and Institute for Food, Nutrition and Well-being, University of \\ Pretoria, Private Bag X20, Hatfield 0028, South Africa
}

*Corresponding author:john.taylor@up.ac.za, Tel:+27 12420 4296, Fax:+27 124202839

\section{Abstract}

Soaking of cereal grains has been suggested as a method to reduce their phytate content and hence increase their mineral availability. Whole and milled wholegrain, normal and low phytate sorghum and normal maize were studied. Soaking of unmilled sorghum and maize did not result in substantial reductions in phytate or mineral contents. With milled grains, phytate solubilisation was somewhat greater in maize than in sorghum after a short (1 hour) soaking period but not after 6-12 hours of soaking when all phytate had been solubilised. Also, with milled, low phyate sorghums, phytate solubilisation was not substantially higher than in their null controls. Soaking milled grain substantially reduced mineral contents and $\mathrm{Ca} x$ 
phytate:zinc molar ratios. However, the loss in soluble minerals could have a greater negative effect on mineral availability, compared to the positive effect of the phytate reduction. Thus, soaking does not seem to be a viable household method to improve sorghum and maize mineral availability.

Keywords:iron, zinc, calcium, magnesium, phosphorus, household method, mineral availability

\section{Introduction}

Mineral deficiencies are highly prevalent in sub-Saharan Africa (WHO, 2006; Tulchinsky 2010). Sorghum (Sorghum bicolor (L.) Moench) and maize (Zea mays) (L.) are important staple crops, often grown (FAO, 2007b) and consumed (FAO, 2007a) by subsistence farmers in sub-Saharan Africa. Like other grains, they are commonly consumed as wholegrain products (Hunt, 2003). The bran contains a substantial portion of the minerals in the grain (Mahgoub and Elhag, 1998). However, the bran also contains factors such as phytate and in the case of sorghum sometimes tannins (Hahn et al., 1984), depending on the cultivar, which inhibit the availability of essential divalent minerals (Hunt, 2003) such as iron (Fe), zinc (Zn), calcium (Ca) and magnesium (Mg).

It has been suggested that soaking of milled cereal grains could be a viable household method to increase the mineral availability by decreasing the phytate content (Hotz and Gibson, 2007). However, findings on the effects of soaking 
unmilled sorghum and maize on their phytate and mineral contents (Table 1) have produced mixed results. While some differences between the phytate properties, e.g. Location of phytate in the grain - O'Dell et al., 1972, phytate profile (Lehrfeld, 1994) and phytate solubility (Egli, 2002) of different cereal grains have been reported, comparison of data from different authors is difficult. This is because different grain cleaning and soaking conditions have been used (Table 1). Differences include volume of soaking liquid, duration of soaking and source of soaking liquid. Additionally, in general, the grains have been poorly characterized in terms of origin and characteristics.

The primary objective of this work was to compare the solubilisation of phytate and minerals in characterised white and red, tannin and non-tannin and low phytate sorghum and white maize grain types. The effects of grain form and various soaking durations were also evaluated. The aim was to determine if aqueous soaking is a viable household method to substantially reduce phytate:mineral molar ratios of sorghum and maize, and thereby improve their mineral availability for human nutrition.

\section{Materials and methods}

\section{Grains- origin, physical and chemical characteristics}

White tan-plant sorghum and white maize were investigated, as these types of sorghum and maize are the most alike (Rooney and Waniska, 2000). Red (anthocyanin-rich) non-tannin sorghum (RNTS) and red (anthocyanin and proanthocyanin-rich) tannin sorghums (RTS) were also included as these types are commonly available in local markets in sub-Saharan Africa, which was a 
characteristic some researchers used to identify the sorghum type they worked with (Table 1).

White tan-plant sorghum hybrids; Orbit (WS1) and NK 8828 (WS2) (both cultivated at the South African Agricultural Research Council, Grain Crops Institute (ARC-GCI), Potchefstroom) and variety Macia (WS3) (cultivated in Botswana), red tannin (type III) sorghum hybrid PAN 3860 (RTS) (kindly donated by PANNAR Seeds, Klerksdorp, South Africa) and red non-tannin sorghum hybrid; MR Buster (RNTS) (cultivated in Botswana) were used. The low phytate transgenic sorghums (early generation Africa Biofortified Sorghum lines) (Kruger et al., 2012) used were the result of backcrossing a transgenic Type II tannin sorghum (parent P898012) into Macia. The modifications included the suppression of myo-inositol kinase synthesis, which reduced the phytic acid synthetic capacity of the plant during seed development (Mendoza, 2002). There were both low phytate white tan-plant (LPWS) and low phytate white type II tannin (LPWTS) sorghum types and their null controls (NC). These were cultivated in 2009 at Johnston, lowa, in summer, in confined field trials and kindly donated by Pioneer Hi-Bred. Due to regulations all these transgenic types were received as coarsely crushed grain. Thus, cleaning was not possible and those analyses requiring unmilled grains could not be performed. The white maize types used were hybrids; PAN 6Q-521 R (WM1), PAN 5Q- 433 B (WM2), and CA 9001 (WM3) and cultivated at the ARC-GCl. Physical and chemical characteristics of these grains are given in Table 2. 


\section{Preparation of milled grains and soaked samples}

\section{Milled wholegrain}

Before milling or soaking, all grains were quickly $( \pm 30 \mathrm{sec})$ rinsed with de-ionised water to remove surface contaminants such as soil minerals or grain dust. The grains were then spread out in a single layer and air dried at $\pm 20^{\circ} \mathrm{C}$ overnight. They were then milled using a laboratory hammer mill (Falling Number 3100, Huddinge, Sweden) fitted with a $500 \mu \mathrm{m}$ opening screen. The resulting flour was stored at $10^{\circ} \mathrm{C}$ in air-tight containers in the dark prior to further preparation or analyses.

\section{Soaking}

Sound unmilled grains and milled grains were all soaked in de-ionised water at a grain:liquid ratio of $1: 5(\mathrm{w} / \mathrm{w})$ at $25^{\circ} \mathrm{C}$ on a mechanical shaker (Grant-Bio POS-300, Cambridgeshire, England), shaking at a rate of $100 \mathrm{rpm}$. Unmilled grains were soaked for 12 hours, while the milled grains were soaked for 45 minutes, 1 hour, 6 hours and 12 hours. After soaking the milled grain, the samples were centrifuged at $4000 \times \mathrm{g}$ for 5 minutes and the supernatant discarded. After soaking the unmilled grain, the supernatant was strained off using a cheese cloth. The grains were then dried, milled and stored as described.

\section{Analyses}

\section{Physical characteristics}

Endosperm texture, defined as the proportion of corneous endosperm relative to floury endosperm in the grain, was determined subjectively by viewing longitudinally 
sectioned kernels ( \pm 20 kernels) using a hand lens (ICC, 2012). Thousand kernel weight (TKW) was determined by weighing 100 randomly selected sound kernels and multiplying the weight by 10 .

\section{Chemical characteristics}

Total phenols were determined using a modified Folin Ciocalteu method (Kaluza et al., 1980). Tannin content was determined by the modified Vanillin $\mathrm{HCl}$ assay (Price et al., 1978). Reagent blanks that corrected for the colour of the flour extracts were included.

\section{Phytate content}

This was determined through anion exchange chromatography, indirect quantitative analysis by measuring the organic phytate phosphorus (inositol -1 to 6 - phosphate) (Frubeck et al., 1995). The resin used was Dowex 1; anion-exchange resin-AG $1 \mathrm{x}$ 4, 4\% cross-linkage, chloride form, 100-200 mesh (Sigma, Johannesburg, South Africa). Spectrophotometer used was a Lambda EZ 150 (Perkin Elmer, Massachusetts, USA)

\section{Mineral analysis}

Mineral analysis was performed by Ion Coupled Plasma-Optical Emission Spectroscopy (ICP-OES) as described by Kruger et al. (2012). 


\section{Statistical analysis}

All data were analysed by single factor ANOVA (significance level $p<0.05$ ) using Statistica 10 (Statsoft, Tulsa, Oklahoma). Linear regression statistics were analysed using Microsoft, Excel 2010.

\section{Results and Discussion}

\section{Effect of aqueous soaking on the phytate contents}

The phytate contents of the normal wholegrain sorghum and maize cultivars varied between $7.9 \pm 0.5$ and $15.2 \pm 2.6 \mathrm{mg} / \mathrm{g}$ (Table 3). The phytate contents of the WS cultivars were higher than that of the other sorghum types and the WM cultivars. However, the phytate contents of all the sorghum types were within the range previously reported for normal sorghum (3-20 mg/g) (Oatway et al., 2001; Kruger et al., 2012; Kruger et al., 2013), The phytate contents of the WM also fell within the range previously reported for normal maize (7-14 mg/ g) (Hotz and Gibson, 2001; Abebe et al., 2007). The phytate contents of the LPWS and LPTWS, while still within the range reported for normal sorghum, were reduced by $48 \%$ and $53 \%$ compared to their respective null controls.

There was only a small reduction in phytate contents when unmilled normal WS $(13 \% \pm 6.1)$ and WM $(14 \% \pm 5.7)$ were soaked, and no difference in the percentage reduction between WS and WM. The percentage phytate reductions in the RNTS and RTS were somewhat lower (12\%) and higher (19\%), respectively, compared to 
the WS and WM but not substantially different. Other authors who soaked unmilled sorghum, used lower grain:liquid ratios and found lower percentage reductions (23\%) (Mahgoub and Elhag, 1998), while those who did not clean the grains found similar to slightly higher percentage reductions (approx. 25\%) (Kayodé et al., 2007) (Table 1). When longer soaking duration and changing the soaking liquid was employed, higher percentage reductions (23-32\%) (Afify et al., 2011) were found.

In studies that compared the effect of soaking on the phytate content of unmilled sorghum and maize grains, the findings contrasted somewhat with that of this present work. Lestienne et al. (2005) found that soaking sorghum grain reduced its phytate content by a much lower percentage $(4 \%)$ compared to maize $(21 \%)$. However, no explanation for the difference was provided. There were significant differences in the soaking conditions and method of phytate analysis compared to the work reported here., Lestienne et al. (2005) cleaned the grains by soaking them in $1 \%$ bleach and only the inositol hexaphosphate was measured, in contrast to the phytate phosphorus in the current study. Egli et al. (2002) found that soaking did not reduce the phytate contents of unmilled sorghum and maize grains. As the article of Egli et al. (2002) focussed more on germination than soaking, the methodology was not clear as to if the soaking liquid was removed and if so how it was done.

Soaking milled wholegrain reduced the phytate content substantially more than soaking the unmilled grains. Also, the phytate reduction of WM (57\% \pm 10 reduction) was proportionally more than that of WS $(39 \% \pm 9.2$ reduction) (Table 3$)$. The phytate reduction of the RNTS (46\% reduction) and RTS (47\% reduction) was intermediate, 
but still somewhat lower than the WM. Notably, the phytate present in the low phytate mutants was not more soluble than that in their normal null controls.

The greater reductions in phytate content when soaking milled grain compared to unmilled grain are presumably due to the fact that milling increased the surface area of the grain exposed to the soaking liquid. Similar percentage reductions $(57 \%)$ (Hotz and Gibson, 2001) as found in the current study $(57 \pm 10 \%)$ and lower percentage reductions (50\%) (Hotz et al., 2001; Hotz and Gibson, 2001) in phytate were found when milled and pounded maize, respectively, were soaked in distilled water. This suggests that even the degree of milling could also affect the phytate solubilisation during soaking.

It appears that the differences in phytate reduction between milled sorghum and maize (Table 3) were in fact related to the differences in their original phytate contents. If the amount by which the phytate contents was reduced is considered, the range of reductions $(4.0-7.2 \mathrm{mg} / \mathrm{g}$, values in square brackets) differed only by 3 $\mathrm{mg} / \mathrm{g}$ between all the grains. However, the range of phytate contents of the milled grains after soaking $(2.8-9.7 \mathrm{mg} / \mathrm{g})$ differed by $7 \mathrm{mg} / \mathrm{g}$. It thus appears that under the particular conditions of soaking (liquid volume, soaking $\mathrm{pH}$, temperature and time) only a certain quantity of phytate could be solubilised. This could have resulted in the grains with higher phytate content having smaller percentage reductions in phytate content, as observed. In fact, it has been found that factors such as higher volume of soaking liquid, longer soaking times as well as more efficient removal of the liquid increased the percentage phytate loss (Hotz and Gibson, 2001). 
Due to the fact that the ratio of grain to soaking liquid (1:5) was already as high or higher than the other studies (Table 1), the effect of soaking time on the phytate content of milled grain was then investigated (Figure 1). Further substantial reductions in the phytate contents of sorghum and maize occurred (reduced to 1.4$2.8 \mathrm{mg} / 100 \mathrm{~g}$ ) with longer soaking (6 hours). Both cereals were almost completely dephytinised after 12 hours of soaking. The effect of soaking duration on sorghum and maize phytate contents followed exponential curves. The rate of decrease for WS $(0.181-0.204)$ was higher than WM $(0.133-0.152)$, probably owing to the fact that after 12 hours of soaking the phytate contents of both grains were extremely low $(1.0-1.4 \mathrm{mg} / 100 \mathrm{~g})$. This is despite the original phytate contents of the sorghums being substantially higher than the maize types (Table 3). It has similarly been found that soaking rice flour for a prolonged period (6 hours) also resulted in the flour being almost completely dephytinised (Perlas and Gibson, 1998).

A probable reason for the difference in effect of soaking on milled WS, WM and RNTS and RTS phytate solubilisation was the slight differences in the $\mathrm{pH}$ of flours in the de-ionised water. The pHs of the milled grains when they were soaked for 1 hour were as follows: WS pH 6.2-6.7, RNTS and RTS pH 6.2-6.3 and WM pH 5.96.1. Phytate solubilisation is higher at low $\mathrm{pH}$, where it more easily dissociates from its complexes (Oatway et al., 2001).

The solubilisation of phytate is strongly affected by the compounds which it is associated with (De Boland et al., 1975). Protein can form insoluble complexes with phytate (Feil, 2001), possibly resulting in lower phytate reduction during soaking. Table 4 shows that soaking resulted in similar protein loss in the milled WS 
$(12 \% \pm 0.25)$ and WM $(9 \% \pm 0.58)$ (taking into account loss in solid matter). It has been found that during soaking, phytate did not bind with maize albumins and no insoluble complexes were formed (O'Dell and De Boland, 1976). The authors concluded that despite their presence in the maize protein, the lysine, arginine and histidine (amino acids prone to binding phytate), were possibly not accessible to the phytate and hence it did not bind. The authors found the same result when using high lysine maize, strengthening their theory.

Regarding the lower phytate solubilisation of WS compared to WM (Table 3); if phytate-protein complexation in sorghum had instead been higher compared to maize, smaller losses in protein compared to the WM would have been expected.

This was found In the case of the RNTS and RTS where the loss in protein as a result of soaking was substantially lower (5\%), compared to the WS and WM (Table 4). This lower protein loss, however, is most likely due to the phenolic compounds present in RTS and RNTS, which bind to proteins (Bravo, 1998), and not to the phytate.

There was no substantial difference in phytate solubilisation between the milled low phyate sorghum and their Null controls (Table 5). However, soaking milled low phytate sorghum grains and their NCs resulted in greater percentage reductions in phytate (62-79\%) (Table 5) compared to the normal sorghum and maize grains (3957\%) (Table 3). This could possibly be due to the fact that the transgenic sorghum and its null controls were stored in a crushed form, in order to comply with regulations governing the handling of GM plant material. During prolonged storage, 
especially in a milled or crushed form, phytate has been found to degrade (Schlemmer et al. 2009) to lower, more soluble inositol phosphates (Jackman and Black, 1951).

To analyse the relationship between the effects of all the various soaking treatments on the phytate contents of the white sorghum and maize types, data from Table 3 and Figure 1 were combined and subjected to linear regression analysis (Figure 2). There was an excellent linear relationship between sorghum and maize with a very high correlation $(r=0.96)(p<0.001)$. This clearly shows that there was no substantial difference between the solubilisation of phytate in sorghum and maize.

\section{Effect of aqueous soaking on the mineral contents and phytate:mineral molar ratios}

The mineral contents of the WS and WM grains (Table 6) were similar to previously reported values for sorghum: P (FAO, 1995; Glew et al., 1997), Fe (FAO, 1995; Matuschek ,t al., 2001), Zn (FAO, 1995), Ca (FAO, 1995; Kruger et al., 2013) and Mg (FAO, 1995; Glew et al., 1997), and maize: P (FAO, 1992; Spencer et al., 2000), Fe (FAO, 1992; Umeta et al., 2005), Zn (FAO 1992; Beiseigel et al., 2007; Mendoza et al., 1998; Hotz et al., 2001), Ca (FAO, 1992; Mendoza et al., 2001; Hotz et al., 2001) and Mg (FAO, 1992; Mendoza et al., 2001). However, the mineral contents of the RTS and RNTS were higher than the reported ranges for sorghum. Related to this, while soaking unmilled WS and WM for 12 hours did not result in significant ( $p$ > 0.05 ) reductions in their mineral contents (Table 6), 12 hours of soaking did reduce the mineral contents of the RNTS and RTS substantially. These reductions and the 
high original mineral contents of RNTS and RTS could be due to soil or dust particulate contamination. This is despite the fact that the grains were rinsed. It has been found that in some cases up to $70 \%$ of the iron in some food crops can be from soil or dust particulate inclusion by the plant tissue during its growth (Cary et al., 1994). Such iron could not be removed by washing with chelating agents, or with dilute acids. It was apparently either tightly bound to the plant tissue or present as inclusions in the tissue. The RTS and RNTS, could have contained contamination minerals, which, with prolonged soaking of the unmilled grains, were solubilised.

Soaking milled grains resulted in substantial reductions in all the measured minerals except Fe (Table 6). Again, the percentage reduction in mineral contents of the RTS and RNTS was substantially higher than that of the WM and WS. For this reason, the quantity $(\mathrm{mg} / \mathrm{kg})$ of mineral solubilised during soaking of the unmilled grain was subtracted from the quantity of the same mineral solubilised during soaking of the milled grain. The resulting data were used to calculate the percentage reductions in mineral contents of the milled RTS and RNTS (Table 6, square brackets), as compared to the original grains. The reductions were similar to those of the WS and WM. This supports the theory that contamination minerals in RTS and RNTS were solubilised when the unmilled grains and milled grains were soaked.

Significantly, WM P contents were reduced more than those of the WS. This corresponds to the greater percentage reduction in phytate content (Table 3). There was no difference in the percentage reduction of $\mathrm{Fe}, \mathrm{Zn}$, and $\mathrm{Ca}$ between the WS and WM. The percentage reduction in $\mathrm{Mg}$ of the $\mathrm{WM}$ was somewhat higher 
compared to the WS. This is probably due to the fact that phytate-Mg complexes are soluble in aqueous solutions (Hotz and Gibson, 2007). This suggests that the greater reduction in phytate content of the WM compared to the WS (Table 3) was due to solubilisation of phytate-Mg complexes. No literature could be found on the effect of soaking cereals on their Mg content. Importantly, studies that soaked sorghum and maize in mineral or tap water (Table 2), did not measure the mineral contents of the water. $\mathrm{Fe}, \mathrm{Zn}, \mathrm{Ca}$ and $\mathrm{Mg}$ are found in drinking water in moderate amounts in some supplies (WHO, 2005). Thus, studies conducted with tap water cannot be compared to the current study where de-ionised water was used.

Soaking of milled grain, but not unmilled grain, resulted in reductions in phytate:mineral ratios (Figure 3; Table 6). However, none of the phytate:Fe molar ratios were reduced below the proposed critical level of 1 (Hunt, 2003), above which it has been found that iron availability is seriously impaired. Some of the phytate:zinc molar ratios were reduced to within the critical range $>10-14$ (Hunt, 2003) but none of the magnitudes of phytate:zinc ratio reduction were substantial. The greater reductions in phytate:Fe ratio compared to phytate:Zn ratio was due to the fact that a minimal amount of Fe was solubilised into the soaking liquid. The phytate $\mathrm{x} C a: Z n$ ratios of all the samples were substantially reduced. However none of the original grains had phytate $\times \mathrm{Ca}: \mathrm{Zn}$ molar ratios above the critical level of 200 (Morris and Ellis, 1989), except that of WS. With soaking, the phytate $x$ Ca:Zn molar ratio of the WS was reduced from 291 to 165. 
Regarding phytate reduction in tannin type sorghum to increase mineral availability; the proposed phytate mineral ratios (Hunt, 2003) do not take into account the inhibitory effect of tannins on mineral availability. Despite large reductions in phytate content of high tannin sorghums (80\%) (Kruger et al., 2012), (100\%) (Hurrell et al., 2003), it has been found iron availability did not improve, due to the inhibitory action of the tannins.

Soaking of milled sorghum and maize reduced their phytate:mineral ratios because a larger portion of phytate was solubilised into the soaking liquid compared to the portion of minerals which were solubilised (Table 6). However, the loss in soluble minerals from the grain could have a greater negative effect on mineral availability, compared to the positive effect of phytate reduction. This is because mineral bioavailability is measured in sequential series of events (stages), the first stage being mineral solubilisation; when a mineral is released from the food matrix (Fairweather-Tait et al., 2005). Each stage (solubilisation followed by bioaccessibility, uptake, absorption, retention, utilization and storage) has to be achieved for the next stage to be possible. Thus, reducing the quantity of soluble minerals would most probably reduce the amount of bioaccessible minerals in the grain and so forth in the following stages.

Also, an important difference when wholegrain flour is soaked at household level, compared to this study, is that the soaking liquid would not be removed by centrifugation. It has been found that more effective removal of soaking liquid results in greater reductions in phytate content (Hotz and Gibson, 2001). It is highly unlikely 
that any household method would remove the soaking liquid as effectively centrifugation. Thus, it is probable that household methods might result in higher loss of solids, decreasing the quantity of food in already food insecure households.

\section{Conclusions}

Despite some small differences in percentage reductions between studies, it is clear that soaking unmilled sorghum and maize in distilled water does not decrease phytate contents substantially and that there is no difference in phytate solubilisation between the grains. Phytate solubilisation is substantial with milled sorghum and maize. The greater solubilisation of phytate in milled maize is probably due to the higher phytate content of sorghum and the slightly higher $\mathrm{pH}$ of the soaking liquid and not to differences in phytate properties. Soaking milled sorghum and maize for a prolong period (6-12 hours) practically completely dephytinises in both grains, indicating that there is no substantial difference phytate solubilisation between them. At the household level, the loss in soluble minerals which also occurs when milled wholegrain is soaked, could have a greater negative effect on mineral availability to the consumer, compared to the positive effect of the phytate reduction. Thus, while it should still be validated in a human bioavailability trial, soaking does not seem to be a viable household method to improve sorghum and maize mineral availability.

\section{References}

Abebe Y, Bogale A, Hambidge KM, Stoecker BJ, Bailey K, Gibson RS. (2007). Phytate, zinc, iron and calcium content of selected raw and prepared foods 
consumed in rural Sidama, Southern Ethiopia, and implications for bioavailability. $J$ Food Comp Anal 20:161-168.

Afify AEMMR, El-Beltagi HS, Abd El-Salam SM, Omran AA. (2011). Bioavailability of iron, zinc, phytate and phytase activity during soaking and germination of white sorghum varieties.

PLoS ONE 6:e25512. Available at:doi:10.1371/journal.pone.0025512. Accessed on 1 June 2013.

Beiseigel JM, Hunt JR, Glahn RP, Welch RM, Menkir A, Maziya-Dixon BB. (2007). Iron bioavailability from maize and beans:a comparison of human measurements with Caco-2 cell and algorithm predictions. Am J Clin Nutr 86:388-396.

Bravo L. (1998). Polyphenols: Chemistry, dietary sources, metabolism and nutritional significance. Nutr Rev 56:317-333.

Cary EE, Grunes DL, Dallyn SL, Pearson A, Peck NH, Hulm RS. (1994). Plant Fe, Al and $\mathrm{Cr}$ concentrations in vegetables as influenced by soil inclusion. J Food Qual 17:467-476.

De Boland AR, Garner GB, O'Dell BL. (1975). Identification and properties of "phytate" in cereal grains and oilseed products. Food Chem 23:1186-1189.

Egli I, Davidsson L, Juillerat MA, Barclay D, Hurrell RF. (2002). The influence of soaking and germination on the phytase activity and phytic acid content of grains and seeds potentially useful for complementary feeding. J Food Sci 67:3484-3488.

Fairweather-Tait S, Lynch S, Hotz C, Hurrell R, Abrahamse A, Beebe S, Bering S, Bukhave K, Glahn R, Hambridge M, Hunt J, Lonnerdal B, Meller D, Mohktar N, Nestel P, Reddy M, Sandberg A, Sharp P, Teucher B, Trinidad TP. (2005). The usefulness of in vitro models to predict the bioavailability of iron and zinc:A consensus statement from the HarvestPlus expert consultation. Inter $\mathrm{J}$ Vit Nutr Res 75:371-374.

FAO. (2007a). Food supply. Available at:

http://faostat.fao.org/site/609/default.aspx\#ancor Accessed on 1 March 2013.

FAO. (2007b). Production. Available at:

http://faostat.fao.org/site/567/default.aspx\#ancor. Accessed on 1 March 2013.

Feil B. (2001). Phytic acid. J New Seed 3:1-35. 
Food and Agriculture Organization (FAO). (1992). Maize in Human Nutrition.http://www.fao.org/docrep/T0395E/T0395E03.htm. Accessed on 1 March, 2013.

Food and Agriculture Organization (FAO).(1995). Sorghum and millets in human nutrition. http://www.fao.org/DOCREP/T0818e/T0818E0e.htm\#Minerals. Accessed on 1 March, 2013.

Frubeck G, Alonso R, Marzo F, Santidrian S. (1995). A modified method for the indirect quantitative analysis of phytate in foodstuffs. Anal Biochem 225:206-212.

Glew RH, Van der Jagt DJ, Lockett C, Grivetti LE, Smith GC, Pastuszyn A, Milson M. (1997). Amino acid, fatty acid and mineral composition of 24 indigenous plants of Burkina Faso. J Food Comp Anal 10:205-217.

Hahn DH, Rooney LW, Earp CF. (1984). Tannins and phenols of sorghum. Cereal Foods World 29:776-779.

Hotz C, Gibson RS, Temple L. (2001). A home-based method to reduce phytate content and increase zinc bioavailability in maize-based complementary diets. Int $\mathrm{J}$ Food Sci Nutr 52:133-142.

Hotz C, Gibson RS. (2001). Assessment of home-based processing methods to reduce the phytate content and phytate/zinc molar ratio of white maize (Zea mays). $J$ Agric Food Chem 49:692-698.

Hotz C, Gibson RS. (2007). Traditional food-processing and preparation practices to enhance the bioavailability of micronutrients in plant-based diets. J Nutr 137:0971100.

Hunt JR. (2003). Bioavailability of iron, zinc, and other trace minerals from vegetarian diets. Am J Clin Nutr 78:633S-639S.

Hurrell RF. (2003). Influence of vegetable protein sources on trace element and mineral bioavailability. J Nutr 133:2973S-2977S.

International Association for Cereal Science and Technology (ICC). (2012). Standard Method 176:Estimation of Sorghum Grain Endosperm Texture. Vienna:ICC.

Jackman RH, Black CA. (1951). Solubility of iron, aluminum, calcium, and magnesium inositol phosphates at different pH values. Soil Sci 72:179-186. 
Kaluza WZ, McGrath RM, Robberts C, Schroeder HH. (1980). Separation of phenolics of sorghum bicolor (L.) Moench grain. J Agric Food Chem 28:1191-1196.

Kayodé APP, Hounhouigan JD, Nout MJR. (2007). Impact of brewing process operations on phytate, phenolic compounds and in vitro solubility of iron and zinc in opaque sorghum beer. Food Sci Tech 40:834-841.

Kruger J, Taylor JRN, Oelofse A. (2012). Effects of reducing phytate content in sorghum through genetic modification and fermentation on in vitro iron availability in wholegrain porridges. Food Chem 131:220-224.

Kruger J, Taylor JRN, Du X, De Moura F.F, Lönnerdal B, Oelofse A. (2013). Effect of phytate reduction of sorghum, through genetic modification, on iron and zinc availability as assessed by an in vitro dialysability bioaccessibility assay, Caco-2 cell uptake assay, and suckling rat pup absorption model. Food Chem. 141:1019-1025.

Lehrfeld J. (1994). HPLC separation and quantitation of phytic acid and some inositol phosphates in foods:problems and solutions. J Agric Food Chem 42:2726-2731.

Lestienne I, Icard-Vernière C, Mouquet C, Picq C, Treche S. (2005). Effects of soaking whole cereal and legume seeds on iron, zinc and phytate contents. Food Chem 89:421-425.

Mahgoub SEO, Elhag SA. (1998). Effect of milling, soaking, malting, heat-treatment and fermentation of phytate level of four Sudanese sorghum cultivars. Food Chem 61:77-80.

Matuschek E, Towo E, Svanberg U. (2001). Oxidation of polyphenols in phytatereduced high-tannin cereals:effect on different phenolic groups and on in vitro accessible iron. J Agric Food Chem 49:5630-5638.

Mendoza C, Viteri FE, Lönnerdal B, Raboy V, Young KA, Brown KH. (2001). Absorption of iron from unmodified maize and genetically altered, low-phytate maize fortified with ferrous sulfate or sodium iron EDTA. Am J Clin Nutr 73:80-85.

Mendoza C, Viteri FE, Lönnerdal B, Young KA, Raboy V, Brown KH.(1998). Effect of genetically modified, low-phytic acid maize on absorption of iron from tortillas. Am J Clin Nutr 68:1123-1127.

Mendoza C. (2002). Effect of genetically modified low phytic acid plants on mineral absorption.Int J Food Sci Tech 37:759-767. 
Morris ER, Ellis R. (1989). Usefulness of the dietary phytic acid/zinc molar ratio as an index of zinc bioavailability to rats and humans. Biol Trace Elem Res 19:107-117. O'Dell BL, de Bowland AR, Koirtyohann SR. (1972). Distribution of phytate and nutritionally important elements among the morphological components of cereal grains. J Agric Food Chem 20:718-721.

Oatway L, Vasanthan T, Helm J.H. (2001). Phytic acid. Food Rev Int 17:419-431.

O'Dell BL, De Boland A. (1976). Complexation of phytate with proteins and cations in corn germ and oil seed meals. J Agric Food Chem 24:804-808.

Perlas LA, Gibson RS.(2002). Use of soaking to enhance the bioavailability of iron and zinc from rice-based complementary foods used in the Philippines. J Sci Food Agric 82:1115-1121.

Price ML, Van Scoyoc S, Butler LG. (1978). A critical evaluation of the vanillin reaction as an assay for tannin in sorghum grain. J Agric Food Chem 26:1214-1218.

Rooney LW, Waniska RD. (2000).Food and industrial utilization. In:Smith CW, Frederiksen R.A, eds. Sorghum, Origin, History, Technology and Production. New York:John Wiley and Sons, 689-729.

Schlemmer U, Frølich W, Prieto RM, Grases F. (2009). Phytate in foods and significance for humans:food sources, intake, processing, bioavailability, protective role and analysis. Mol Nutr Food Res 53:S330-S375.

Spencer JD, Allee GL, Sauber TE. (2000). Phosphorus bioavailability and digestibility of normal and genetically modified low-phytate corn for pigs. J Anim Sci 78:675-681.

Temple L, Gibson RS, Hotz C. (2002).Use of soaking and enrichment for improving the content and bioavailability of calcium, iron and zinc in complementary foods and diets of rural Malawian weanlings. J Food Sci 67:1926-1932.

Tulchinsky TH. (2010). Micronutrient deficiency conditions:Global health issues. Public Health Rev 32:243-255.

Umeta M, West C.E, Fufa H. (2005). Content of zinc, iron, calcium and their absorption inhibitors in foods commonly consumed in Ethiopia. J Food Comp Anal 18:803-817. 
World Health Organization (WHO). (2005). Nutrient in drinking water. Geneva, Switzerland:WHO.

World Health Organization (WHO). (2007). Global database on anaemia. Geneva, Switzerland:WHO.

\section{Acknowledgements}

University of Pretoria post-doctoral fellowship for J Kruger. UIS Analytical services (Centurion, South Africa) for the ICP-OES analysis

\section{Declaration of Interest}

There are no financial, consulting or personal relationships with other people of organisations that could influence the authors' work. 
Table 1:Summary of published research on the effect of soaking on the phytate content, iron and zinc contents and availabilities of unmilled grain and milled sorghum and maize

\begin{tabular}{|c|c|c|c|c|}
\hline Reference & Grain characterisation & Grain form & $\begin{array}{c}\text { Parameters } \\
\text { measured }\end{array}$ & Soaking conditions \\
\hline $\begin{array}{l}\text { Mahgoub and } \\
\text { Elhag } 1998\end{array}$ & $\begin{array}{c}\text { Four sorghums:Dabar, Feterita Gadarif, } \\
\text { Feterita, Gazira, Hageen, from a local } \\
\text { market in Sudan }\end{array}$ & Milled wholegrain & Phytate & $\begin{array}{l}\text { Visually cleaned, soaked in tap water } \\
(1: 4 \mathrm{w} / \mathrm{w}) \text { for } 12 \text { and } 24 \text { hours }\end{array}$ \\
\hline $\begin{array}{l}\text { Hotz and } \\
\text { Gibson } 2001\end{array}$ & $\begin{array}{c}\text { Maize imported from Malawi and stored } \\
\text { under refrigeration }\end{array}$ & $\begin{array}{l}\text { Milled and traditionally } \\
\text { pounded }\end{array}$ & Phytate, Zn & $\begin{array}{c}\text { Soaked in tap water }(1: 4 \mathrm{w} / \mathrm{w}) \text { for } 1 \\
\text { hour up to } 24 \text { hours }\end{array}$ \\
\hline Hotz et al. 2001 & Maize & $\begin{array}{l}\text { Traditionally pounded } \\
\text { wholegrain }\end{array}$ & $\begin{array}{l}\text { Phytate, Fe, } \\
\text { Zn }\end{array}$ & $\begin{array}{c}\text { Soaked in tap water }(1: 4, w / w) \text { for } 1 \\
\text { hour }\end{array}$ \\
\hline Egli et al. 2002 & $\begin{array}{c}\text { Sorghum, maize, commercially purchased } \\
\text { between } 1997 \text { and } 1998\end{array}$ & Unmilled wholegrain & Phytate & $\begin{array}{l}\text { Soaked in distilled water }(1: 5 \mathrm{w} / \mathrm{w}) \text { for } \\
16 \text { hour }\end{array}$ \\
\hline $\begin{array}{l}\text { Temple et al. } \\
2002\end{array}$ & $\begin{array}{l}\text { Maize imported from Malawi and stored } \\
\text { under refrigeration for } 24 \text { months }\end{array}$ & Milled wholegrain & Phytate & $\begin{array}{c}\text { Soaked in tap water }(1: 4 \mathrm{w} / \mathrm{w}) \text { for } 1 \\
\text { hour up to } 24 \text { hours }\end{array}$ \\
\hline $\begin{array}{l}\text { Lestienne et al. } \\
\qquad 2005\end{array}$ & $\begin{array}{l}\text { Sorghum and maize, purchased in Burkina } \\
\text { Faso and France, respectively }\end{array}$ & Unmilled wholegrain & Phytate & $\begin{array}{c}\text { Soaked in } 1 \% \text { bleach in water }(1: 3 \\
w / w) \text { for } 15 \text { min then in mineral water } \\
(1: 3 \mathrm{w} / \mathrm{w}) \text { for } 24 \text { hours }\end{array}$ \\
\hline $\begin{array}{l}\text { Kayodé et al. } \\
2007\end{array}$ & $\begin{array}{l}\text { Three red sorghums, from a local market in } \\
\text { Parakou, Benin }\end{array}$ & Milled wholegrain & $\begin{array}{l}\text { Phytate, Fe, } \\
\text { Zn }\end{array}$ & $\begin{array}{c}\text { Soaked overnight ( } \pm 12 \text { hours), no } \\
\text { indication if tap/distilled water was } \\
\text { used }\end{array}$ \\
\hline Afify et al. 2011 & $\begin{array}{l}\text { Three white sorghums, harvested } 2007 \text {, } \\
\text { obtained from the CASC, Giza, Egypt }\end{array}$ & Milled wholegrain & $\begin{array}{l}\text { Phytate, Fe, } \\
\text { Zn }\end{array}$ & $\begin{array}{c}\text { Visually cleaned, soaked in distilled } \\
\text { water which was changed twice (1:5 } \\
\text { w/w) for } 20 \text { hours }\end{array}$ \\
\hline
\end{tabular}


Table 2:Chemical (tannin and total phenol content) and physical (1000 kernel weight and endosperm texture) properties of sorghum and maize grains

\begin{tabular}{|c|c|c|c|c|c|c|c|c|}
\hline \multirow{2}{*}{\multicolumn{2}{|c|}{ Grain type }} & \multirow[t]{2}{*}{ cultivar } & \multirow{2}{*}{$\begin{array}{l}\text { Thousand } \\
\text { kernel } \\
\text { weight (g) }\end{array}$} & \multicolumn{3}{|c|}{$\begin{array}{c}\text { Grain endosperm texture (relative } \\
\% \text { ) }\end{array}$} & \multirow{2}{*}{$\begin{array}{c}\text { Tannin } \\
\text { Content (CE } \\
\mathrm{g} / 100 \mathrm{~g}) \mathrm{db}\end{array}$} & \multirow{2}{*}{$\begin{array}{l}\text { Total phenol } \\
\text { content (CE } \\
\mathrm{g} / 100 \mathrm{~g}) \mathrm{db}\end{array}$} \\
\hline & & & & Corneous & Intermediate & Floury & & \\
\hline \multirow{3}{*}{ Sorghum } & $\begin{array}{l}\text { White tan- } \\
\text { plant }\end{array}$ & $\begin{array}{l}\text { Orbit, NK8828, } \\
\text { Macia }\end{array}$ & $26(5)$ & $5-55$ & $40-42$ & $3-55$ & $0.30(0.1)$ & $0.15(0.0)$ \\
\hline & $\begin{array}{l}\text { Red non- } \\
\text { tannin }\end{array}$ & MR Buster & 29 & 78 & 20 & 3 & $0.35(0.1)$ & $0.32(0.1)$ \\
\hline & $\begin{array}{l}\text { Red tannin } \\
\text { (type III) }\end{array}$ & PAN 3860 & 26 & 5 & 33 & 63 & $7.44(0.2)$ & $1.33(0.3)$ \\
\hline Maize & White & $\begin{array}{c}\text { PAN 6Q - } 521 \mathrm{R}, \\
\text { PAN 5Q - } 433 \text { B, } \\
\text { CA } 9001\end{array}$ & $333(3)$ & 0 & $10-20$ & $80-90$ & $0.38(0.0)$ & $0.21(0.1)$ \\
\hline
\end{tabular}


Table 3:Effects of soaking unmilled and milled wholegrain sorghum and maize in de-ionised water $25^{\circ} \mathrm{C}$ on their phytate content

\begin{tabular}{|c|c|c|c|c|c|c|}
\hline & \multirow[b]{2}{*}{ Samples } & \multicolumn{5}{|c|}{ Phytate content $(\mathrm{mg} / \mathrm{g}, \mathrm{db})$} \\
\hline & & $\begin{array}{l}\text { Original } \\
\text { grain }\end{array}$ & $\begin{array}{c}\text { Unmilled grain } \\
\text { soaked for } 12 \\
\text { hours }\end{array}$ & $\begin{array}{c}\text { \% reduction } \\
\text { from the } \\
\text { original } \\
\text { grain }\end{array}$ & $\begin{array}{l}\text { Milled wholegrain } \\
\text { soaked for } 1 \text { hour }\end{array}$ & $\begin{array}{c}\text { \% reduction } \\
\text { from the } \\
\text { original } \\
\text { grain }\end{array}$ \\
\hline \multirow{3}{*}{$\begin{array}{l}\text { White tan-plant } \\
\text { sorghum }\end{array}$} & WS1 & $15.2^{\mathrm{K}} \pm 2.6$ & $12.4^{\mathrm{J}} \pm 0.8[2.8]$ & & $9.7^{\mathrm{GHI}} \pm 0.1[5.5]$ & \\
\hline & WS2 & $14.5^{\mathrm{K}} \pm 1.4$ & $12.5^{\lrcorner} \pm 0.4[2.0]$ & $13 \% \pm 6.1$ & $7.3^{\mathrm{D}} \pm 1.8[7.2]$ & $39 \% \pm 9.2$ \\
\hline & WS3 & $12.5^{\mathrm{J}} \pm 0.5$ & $11.7^{\lrcorner} \pm 0.5[0.8]$ & & $8.5^{\mathrm{EF}} \pm 0.9[4.0]$ & \\
\hline $\begin{array}{l}\text { Red non-tannin } \\
\text { sorghum }\end{array}$ & RNTS & $9.9^{\mathrm{HI}} \pm 0.2$ & $8.7^{\mathrm{EFG}} \pm 0.9[1.2]$ & $12 \%$ & $5.3^{C} \pm 0.8[4.6]$ & $46 \%$ \\
\hline $\begin{array}{l}\text { Red tannin (type } \\
\text { III) sorghum }\end{array}$ & RTS & $9.9^{\prime} \pm 1.2$ & $8.0^{\mathrm{DEF}} \pm 0.6[1.9]$ & $19 \%$ & $5.2^{C} \pm 0.5[4.7]$ & $47 \%$ \\
\hline \multirow{3}{*}{ White maize } & WM1 & $7.9^{D E} \pm 0.5$ & $7.2^{\mathrm{D}} \pm 0.7[0.7]$ & & $3.9^{\mathrm{B}} \pm 0.8[4.0]$ & \\
\hline & WM2 & $8.9^{\mathrm{EFGH}} \pm 0.6$ & $7.1^{\mathrm{D}} \pm 0.7[1.8]$ & $14 \% \pm 5.7$ & $2.8^{A} \pm 0.4[6.0]$ & $57 \% \pm 10$ \\
\hline & WM3 & $10.5^{1} \pm 0.4$ & $9.1^{\mathrm{FGH}} \pm 0.5[1.4]$ & & $5.1^{\mathrm{C}} \pm 0.9[5.4]$ & \\
\hline
\end{tabular}

Values are the average $\pm 1 S D$ of at least 2 samples analysed in duplicate

$A B C$ - Phytate contents with different superscripts in the table differ significantly $(p<0.05)$

[] - Magnitude $(\mathrm{mg} / \mathrm{g})$ of phytate reduction 
Table 4:Effects of soaking milled wholegrain sorghum and maize in de-ionised water at $25^{\circ} \mathrm{C}$ for 1 hour on dry matter and protein loss

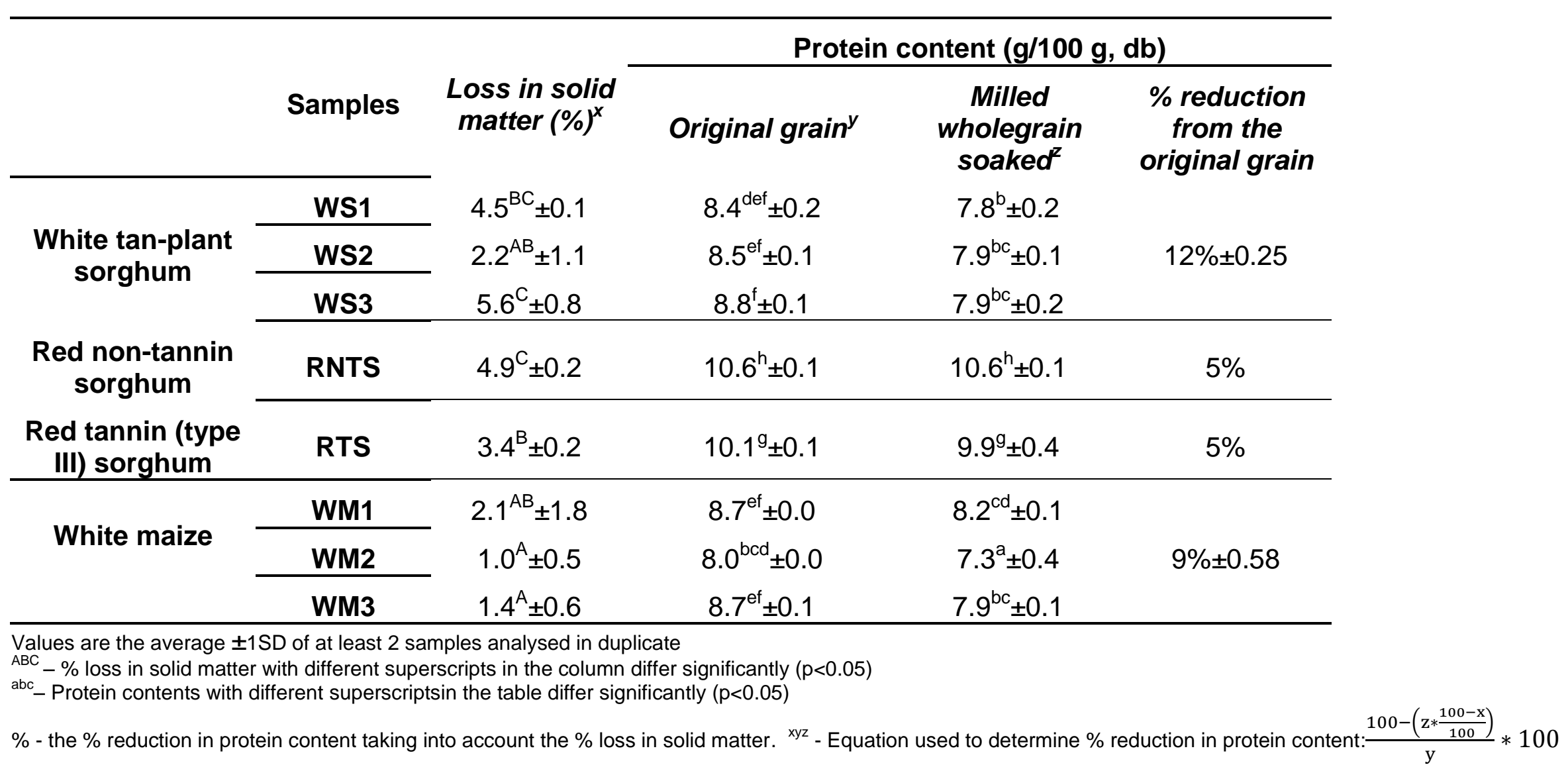


Table 5:Effect of soaking milled wholegrain low phytate sorghum in de-ionised water at $25^{\circ} \mathrm{C}$ for 1 hour on their phytate content

\begin{tabular}{cccc}
\hline \multirow{2}{*}{ Samples } & \multicolumn{3}{c}{ Phytate content $(\mathrm{mg} / \mathrm{g}, \mathrm{db})$} \\
\cline { 2 - 4 } & Original grain & $\begin{array}{c}\text { Soaked milled } \\
\text { wholegrain }\end{array}$ & $\begin{array}{c}\% \text { reduction from } \\
\text { the original grain }\end{array}$ \\
\hline NCWS & $10.7^{\mathrm{H}} \pm 0.7$ & $2.3^{\mathrm{BC}} \pm 0.2$ & $79 \%$ \\
\hline LPWS & $5.6^{\mathrm{E}} \pm 0.0[48 \%]$ & $1.8^{\mathrm{B}} \pm 0.5$ & $68 \%$ \\
\cline { 1 - 1 } NCTWS & $9.3^{\mathrm{G}} \pm 0.4$ & $2.6^{\mathrm{C}} \pm 0.2$ & $72 \%$ \\
\hline LPTWS & $4.4^{\mathrm{D}} \pm 0.5[53 \%]$ & $1.7^{\mathrm{B}} \pm 0.0$ & $62 \%$ \\
\hline
\end{tabular}

Values are the average $\pm 1 S D$ of at least 2 samples analysed in duplicate

[] - Values in square brackets are the percentage reductions in phytate content of the transgenic lines compared to their respective NC

$A B C$ - Values with different superscripts differ significantly $(p<0.05)$ 
Table 6:Effects of soaking unmilled and milled wholegrain sorghum and maize in de-ionised water $25^{\circ} \mathrm{C}$ on their mineral contents (P, Fe, Zn, Ca and Mg) and phytate:mineral molar ratios

\begin{tabular}{|c|c|c|c|c|c|c|}
\hline & Samples & Original grain & $\begin{array}{l}\text { Unmilled grain } \\
\text { soaked for } 12 \text { hours }\end{array}$ & $\begin{array}{c}\% \\
\text { reduction } \\
\text { from the } \\
\text { original } \\
\text { grain }\end{array}$ & $\begin{array}{c}\text { Milled } \\
\text { wholegrain } \\
\text { soaked in for } 1 \\
\text { hour }\end{array}$ & $\begin{array}{c}\% \\
\text { reduction } \\
\text { from the } \\
\text { original } \\
\text { grain }\end{array}$ \\
\hline & \multicolumn{6}{|c|}{$P[\mathrm{mg} / \mathrm{kg}, \mathrm{db}]$} \\
\hline \multirow{3}{*}{ White tan-plant sorghum } & WS1 & $3191^{\prime} \pm 187$ & $3125^{\mathrm{kl}} \pm 99$ & \multirow{3}{*}{ NS } & $1710^{d} \pm 92$ & \multirow{3}{*}{$43 \% \pm 12$} \\
\hline & WS2 & $2862^{\mathrm{j} \mathrm{k}} \pm 324$ & $3233^{1} \pm 77$ & & $1342^{c} \pm 83$ & \\
\hline & WS3 & $2673^{\mathrm{ij}} \pm 375$ & $2829^{\mathrm{i}} \pm 145$ & & $1864^{\mathrm{de}} \pm 94$ & \\
\hline Red non-tannin sorghum & RNTS & $2327^{g h} \pm 16$ & $1888^{\mathrm{de}} \pm 5$ & $19 \%$ & $1261^{c} \pm 164$ & $46 \%$ \\
\hline \multirow[t]{2}{*}{ Red tannin (type III) sorghum } & RTS & $2208^{\operatorname{tgh}} \pm 161$ & $2085^{\mathrm{efg}} \pm 81$ & NS & $1265^{c} \pm 72$ & $43 \%$ \\
\hline & WM1 & $1845^{\mathrm{de}} \pm 8$ & $1983^{\mathrm{def}} \pm 62$ & & $767^{b} \pm 30$ & \multirow{3}{*}{$61 \% \pm 2.5$} \\
\hline \multirow[t]{4}{*}{ White maize } & WM2 & $1879^{\mathrm{de}} \pm 33$ & $1866^{\mathrm{de}} \pm 74$ & NS & $706^{b} \pm 23$ & \\
\hline & WM3 & $2341^{g h} \pm 164$ & $2485^{\mathrm{hi}} \pm 21$ & & $868^{b} \pm 51$ & \\
\hline & \multicolumn{6}{|c|}{$\mathrm{Fe}[\mathrm{mg} / \mathrm{kg}, \mathrm{db}]$} \\
\hline & WS1 & $81^{\text {bcd }} \pm 9\{16\}$ & $81^{\text {bcd }} \pm 4\{13.1\}$ & & $89^{\text {bcde }} \pm 2\{9.2\}$ & \\
\hline \multirow[t]{2}{*}{ White tan-plant sorghum } & WS2 & $73^{\mathrm{bc}} \pm 0\{17\}$ & $86^{\mathrm{bcd}} \pm 12\{12.4\}$ & NS & $73^{\mathrm{bc}} \pm 0\{8.4\}$ & NS \\
\hline & WS3 & $110^{\text {cdefg }} \pm 25\{10\}$ & $127^{\text {efgh }} \pm 0\{7.8\}$ & & $97^{\text {bcde }} \pm 7\{7.4\}$ & \\
\hline
\end{tabular}




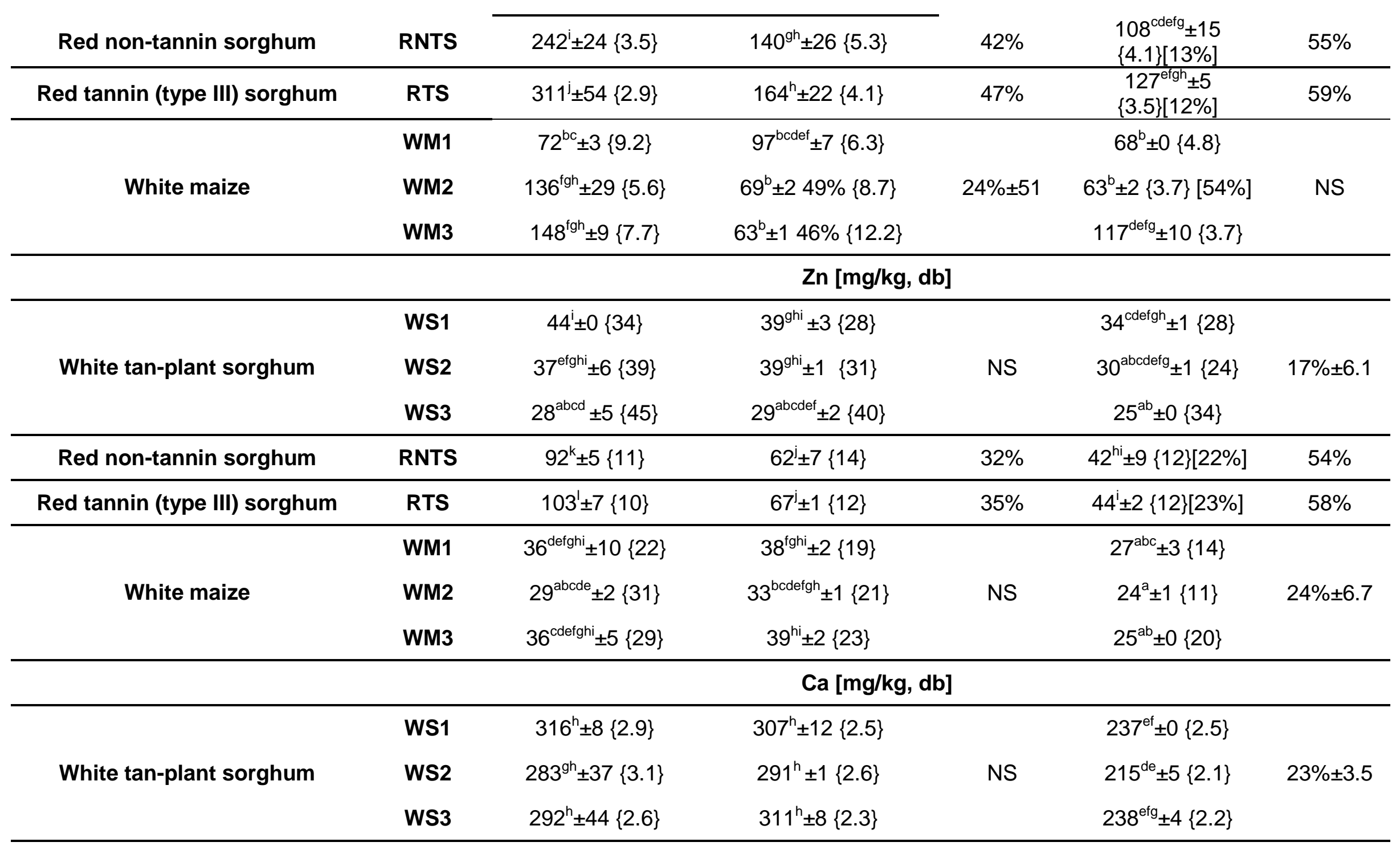




\begin{tabular}{|c|c|c|c|c|c|c|}
\hline \multirow[b]{2}{*}{ Red non-tannin sorghum } & \multirow[b]{2}{*}{ RNTS } & & & & \multirow[b]{2}{*}{$\begin{array}{c}272^{f^{g h}} \pm 40 \\
\{1.2\}[20 \%]\end{array}$} & \multirow[b]{2}{*}{$55 \%$} \\
\hline & & $605^{k} \pm 40\{1.0\}$ & $390^{i} \pm 39\{1.4\}$ & $35 \%$ & & \\
\hline Red tannin (type III) sorghum & RTS & $602^{k} \pm 42\{1.1\}$ & $447^{j} \pm 4\{1.1\}$ & $26 \%$ & $296^{\mathrm{h}} \pm 4\{1.1\}[25 \%]$ & $51 \%$ \\
\hline \multirow{4}{*}{ White maize } & WM1 & $182^{\text {cd }} \pm 6\{2.6\}$ & $184^{\mathrm{bcd}} \pm 22\{2.4\}$ & & $149^{b} \pm 0\{1.6\}$ & \\
\hline & WM2 & $184^{\mathrm{cd}} \pm 7\{2.9\}$ & $165^{\mathrm{bc}} \pm 2\{2.6\}$ & NS & $147^{b} \pm 9\{1.1\}$ & $19 \% \pm 1.4$ \\
\hline & WM3 & $177^{\mathrm{cd}} \pm 3\{3.6\}$ & $195^{\mathrm{cde}} \pm 25\{2.8\}$ & & $140^{b} \pm 9\{2.2\}$ & \\
\hline & \multicolumn{6}{|c|}{$M g[m g / k g, d b]$} \\
\hline \multirow{3}{*}{ White tan-plant sorghum } & WS1 & $1727^{i} \pm 36\{0.32\}$ & $1778^{\mathrm{i}} \pm 40\{0.26\}$ & & $943^{\mathrm{de}} \pm 34\{0.38\}$ & \\
\hline & WS2 & $1510^{\mathrm{hi}} \pm 163\{0.35\}$ & $1744^{i} \pm 74\{0.26\}$ & NS & $728^{\mathrm{cd}} \pm 32\{0.37\}$ & $40 \% \pm 15$ \\
\hline & WS3 & $1375^{g h} \pm 198\{0.33\}$ & $1532^{h i} \pm 119\{0.28\}$ & & $1053^{\mathrm{ef}} \pm 51\{0.30\}$ & \\
\hline Red non-tannin sorghum & RNTS & $3564^{\prime} \pm 128\{0.10\}$ & $2211^{\mathrm{j}} \pm 76\{0.14\}$ & $38 \%$ & $\begin{array}{c}958^{\mathrm{de}} \pm 279 \\
\{0.20\}[35 \%]\end{array}$ & $73 \%$ \\
\hline \multirow[t]{2}{*}{ Red tannin (type III) sorghum } & RTS & $3621^{\prime} \pm 504\{0.11\}$ & $2630^{k} \pm 150\{0.11\}$ & $27 \%$ & $\begin{array}{c}1026^{\mathrm{et}} \pm 16 \\
\{0.19\}[45 \%]\end{array}$ & $72 \%$ \\
\hline & WM1 & $1060^{\mathrm{ef}} \pm 2\{0.27\}$ & $1137^{\mathrm{efg}} \pm 38\{0.23\}$ & & $469^{b c} \pm 8\{0.3\}$ & \\
\hline \multirow[t]{2}{*}{ White maize } & WM2 & $1022^{\mathrm{ef}} \pm 0\{0.32\}$ & $1004^{\text {def }} \pm 25\{0.26\}$ & NS & $429^{b} \pm 10\{0.24\}$ & $57 \% \pm 1.4$ \\
\hline & WM3 & $1206^{\mathrm{efg}} \pm 8\{0.32\}$ & $1278^{\mathrm{fgh}} \pm 43\{0.26\}$ & & $503^{b c} \pm 1\{0.38\}$ & \\
\hline
\end{tabular}

Values are the average \pm 1 SD of at least 2 samples analysed in duplicate

abc - Values with different superscripts differ significantly $(p<0.05)$ for each particular mineral

\{\} - phytate:mineral molar ratio

[] -The amount $(\mathrm{mg} / \mathrm{kg})$ of mineral solubilised during soaking of the wholegrain was subtracted from the amount of the same mineral solubilised

during soaking of the milled grain. The value was used to calculate the \% reduction in mineral content compared to the original grain

NS - If the reduction in phytate content to the value of the original grains are not significant 


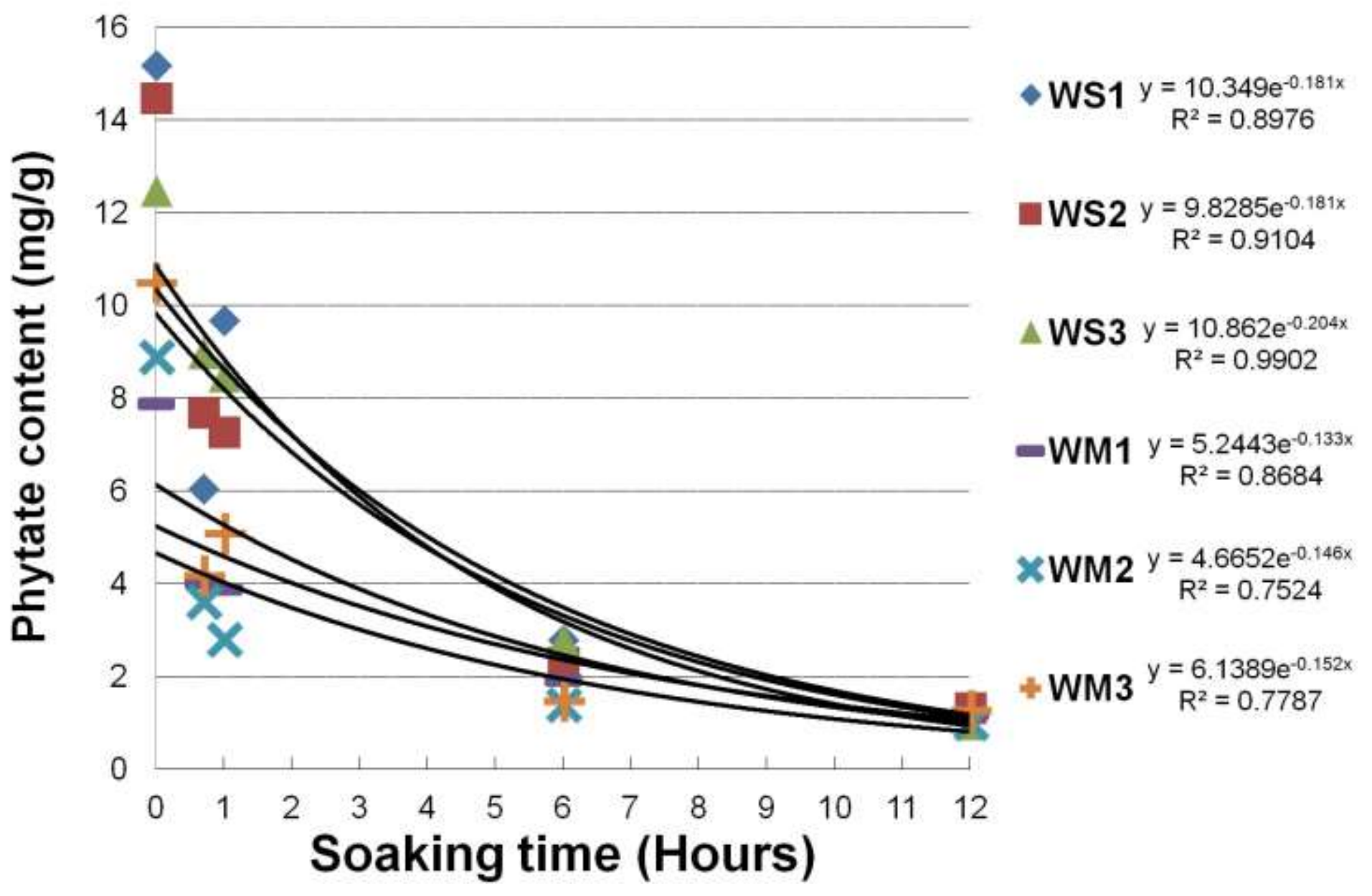

Figure 1:Effects of soaking milled wholegrain white tan-plant sorghum and white maize in de-ionised water for up to 12 hours on their phytate content 


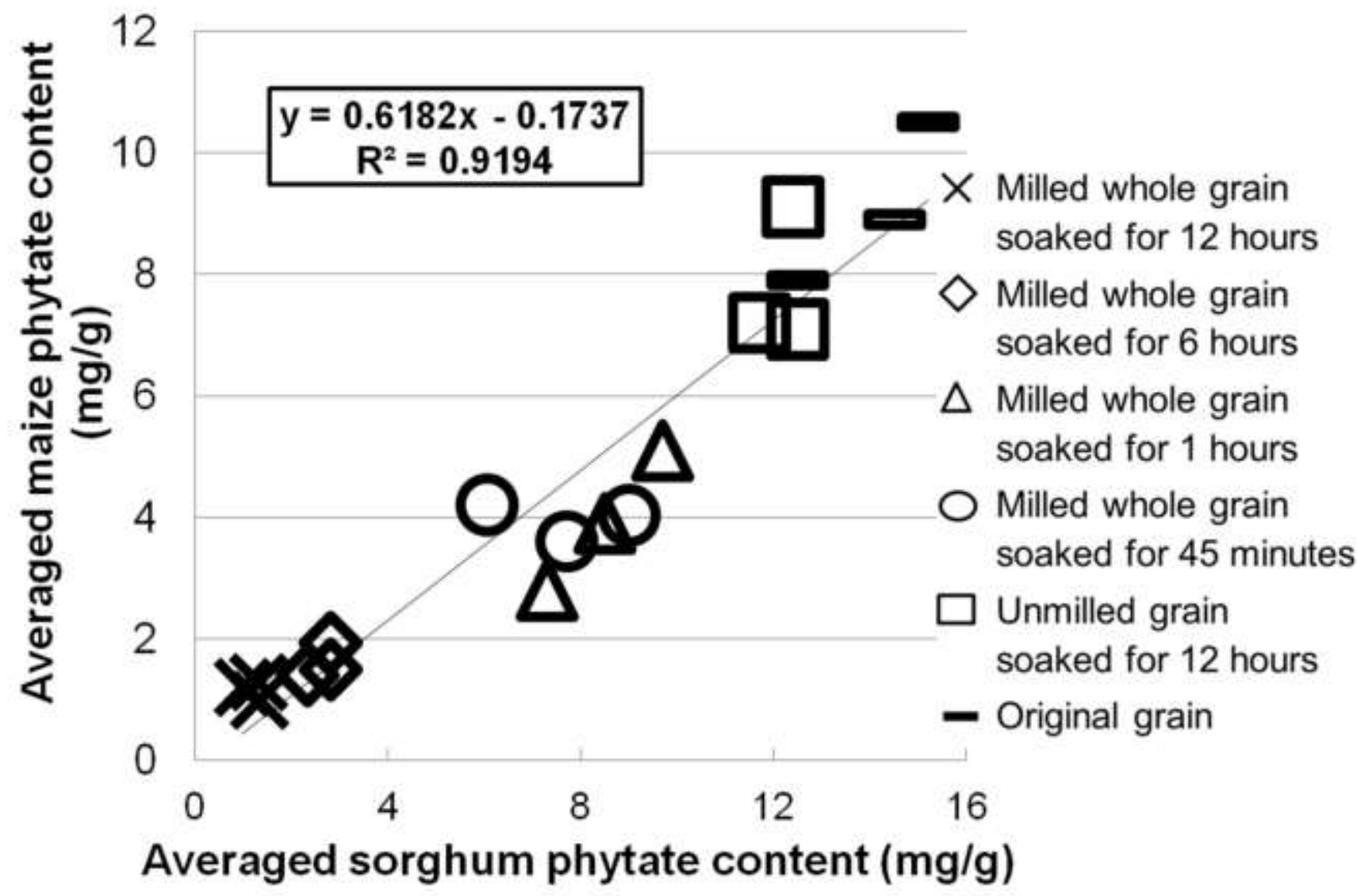

Figure 2:Relationship between the phytate content of white non-tannin sorghum and maize soaked for varying durations 


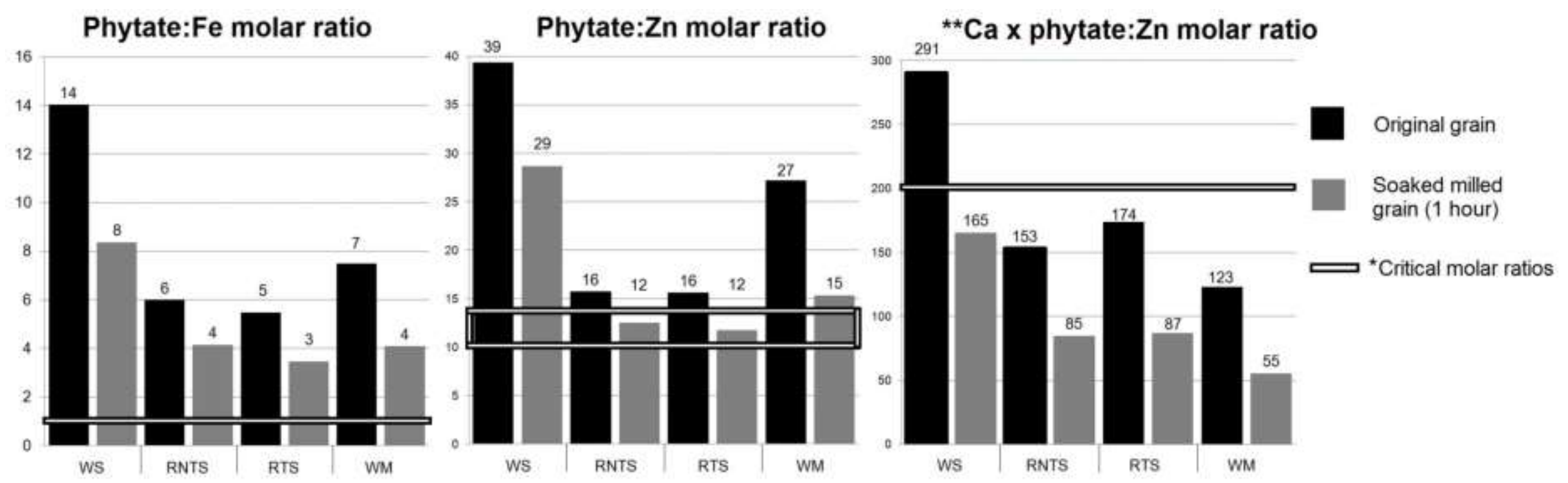

Figure 3:Effects of soaking milled wholegrain sorghum and maize in de-ionised water at $25^{\circ} \mathrm{C}$ for 1 hour on the phytate:mineral molar ratios.

${ }^{*}$ Critical levels above which it has been found that iron (>1, Hunt 2003), and zinc (>10-14' Hunt 2003 and >200,'Morris and Ellis 1989) availability is seriously impaired ${ }^{\star \star}$ Ca $x$ phytate:zinc- Moles of calcium times moles of phytate to moles of zinc

RNTS and RTS values - Mineral contents use to calculate ratios are the reduction of the wholegrain after soaking subtracted from that of the milled grain, to compensate for likely contamination in these grains 